EESTI NSV TEADUSTE AKADEEMIA TOIMETISED. VIII KOIDE

BIOLOOGILINE SEERIA, 1959, NR. 1

ИЗВЕСТИЯ АКАДЕМИИ НАУК ЭСТОНСКОИ ССР. ТОМ VIII

СЕРИЯ БИОЛОГИЧЕСКАЯ. 1959, № 1

\title{
EESTIS KASVATATAVATE VIINAPUUDE BIOLOOGILISEST KARAKTERISTIKAST
}

\section{H. MIIDLA}

Viinapuu kuulub viinapuuliste (Vitaceae Lindl.) sugukonda, kuhu arvatakse umbes 600 liiki, millest suurem osa kasvab metsikult; ainult väikest osa, umbes 20 liiki, kasutatakse marjade saamiseks, pookealusteks ja dekoratiivtaimedeks.

Viinpuuliste sugukonnas on 11 perekonda; majanduslikku tähtsust omavad kaks: viinapuu (Vitis L.) ja metsviinapuu (Parthenocissus Planch.).

Viinapuu on väga vana kultuur. Juba viis tuhat aastat tagasi kultiveeriti teda Egiptuses ja Süürias. Viinapuu kodumaaks loetakse Kesk-Aasiat ja selle naabermaid. XVII ja XVIII sajandil tõusis viinapuukasvatus õitsvale järjele Euroopas. Nõukogude Liidus hakkas viinapuukasvatus eriti hoogsalt arenema pärast Suurt Sotsialistlikku Oktoobrirevolutsiooni.

Davitaja (1948) on välja töötanud viinapuukasvatuse tööstuslike tsoonide süsteemi Nõukogude Liidus, kusjuures ta on aluseks võtnud aktiivsete temperatuuride summa pungade puhkemisest kuni marjade valmimiseni! Bioloogiliseks nulliks on võetud $+10^{\circ} \mathrm{C}$. Tema arvestuse kohaselt oli viinapuukasvatuse pōhjapiiriks $52^{\circ}$ põhjalaiust.

Käesoleval ajal aga, tänu nõukogude bioloogiateadusele, on see piir nihkunud palju kaugemale pōhja. Väga varajasi Lääne-Euroopa päritoluga ja I. Mitšurini aretatud sorte kasvatatakse isegi Leningradi oblastis $59^{\circ}$ põhjalaiusel. Viimane asjaolu viitab ka sellele, et ei ole õige mõōta viinapuukasvatuse põhjapiiri ainult aktiivsete temperatuuride summa alusel, vaid peab silmas pidama kõiki viinapuu kasvu mõjutavaid tegureid.

Viinapuu aretamise ja tema kasvupiiri pōhja poole nihutamise alal Nõukogude Liidus oli pioneeriks I. Mitšurin. Käesoleval ajal tegelevad selle küsimusega mitmed uurimisasutused, nagu Oleliiduline Viinapuukasvatuse Uurimise Instituut, K. A. Timirjazevi nimeline Põllumajanduse Akadeemia, NSVL TA Peabotaanikaaed, ja paljud asjaarmastajad.

Viinapuu kasvatamise kohta avamaal ilmusid Eestis esimesed kirjalikud teated 1887. aastal ajalehes «Virulane». Mõisate kasvuhoonetes (nii soe- kui ka külmkasvuhoonetes) kasvatati neid juba XVIII sajandi esimesel poolel.

Looduslikke tingimusi Eesti NSV-s ei saa pidada viinapuukasvatusele heaks, kuid vaatamata sellele on viinapuu siin siiski püsima jäänud nii avamaa-, seinaäärse kui ka külmkasvuhoone-kultuurina (Mätlik, 1946). Seinaäärse kultuurina annab ta lehviku tüüpi põõsa kohta igal aastal kuni $35 \mathrm{~kg}$ väärtuslikke marju (asjaarmastaja Tuulase teateil, kes elab Tartus Tähe t. 96). Nõukogude Liidus kasvatatakse külm- ja soekasvuhoonetes viinapuid kõige laialdasemalt Balti vabariikides, kus põõsalt saadakse keskmiselt 5-10 kg marju (Pētersons, 1953).

Laiemat viinapuude levikut avamaal takistab Eesti NSV oludes lühike vegetatsiooniperiood ja madal õhu keskmine temperatuur. Lõunamaise 
lühipäevakultuurina puitub viinapuu halvasti pika päeva tingimustes ja kannatab hiliste kevadiste või varajaste sügiseste öökülmade all tublisti.

Et lahendada viinapuu kasvatuse küsimus Eestis, selleks tuleb aretada uued kohalikud sordid, mis oleksid sobivad põhjapoolsetes oludes, nimelt lühikese vegetatsiooniperioodiga, suure suhkrusisaldusega ja põ̉hjamaa suve jooksul valmivate võrsetega sordid. Et tulla toime selle ülesandega, on vaja teada, milliseid majanduslikult tasuvaid sorte leidub kohalikus kultuurtaimede flooras ja missugused on nende bioloogilised ja majanduslikud iseärasused.

Käesolevas artiklis antakse lühike ülevaade viinapuude inventariseerimise tulemustest Eesti NSV-s ja käsitletakse fenofaaside kaupa meil kasvaval viinapuul toimuvaid bioloogilisi protsesse.

\section{Uurimismaterjal ja -metoodika}

Viinapuude inventariseerimisekspeditsioonid korraldati 1949.-1953. aastani. Leitud viinapuuliigid ja -sordid tunnustati ja kirjeldati. Igast avamaakultuuri liigist ja sordist toodi kaasa paljundusmaterjal, millega rajati vaatlusistandused Tartus EPA aias (20 sorti, kokku 125 põõsast), TRU Botaanikaaias (5 sorti, kokku 10 põõsast) ja ETKVL-i aias (7 sorti, kokku 60 põõsast). Peale selle on ka teistest vennasvabariikidest sorte introdutseeritud, et võrrelda meie omi nendega.

Kogu Eesti NSV territooriumil on 24 vaatluspunktis teinud fenoloogilisi vaatlusi korrespondendid vastavate vaatluslehtede alusel.

Eksperimentaalne uurimine viidi läbi sordiga 'Hamburgi must' (foto 1) Tartus ETKVL-i ja heakorrakontori külmkasvuhoonetes (52 põõsast), seinaäärse sordiga 'Malingre varajane' ETKVL-i aiandis ja individuaalkasvatajate juures (12 põôsast) ning avamaasordiga 'Malingre varajane' (foto 2) ETKVL-i aiandis, Räpina aiandustehnikumis ja EPA aiandis (20 põõsast).

Nagu ülaltoodust nähtub, ei ole katsematerjal koondunud ühte punkti ja katsedki on tehtud tootmistingimustes, võoral baasil. Selline olukord sundis katsetes nõutavate korduste saavutamiseks arvestama mõnikord põõsal ühte võrset kordusena. Peale eelnimetatud sortide on katsetes võrreldud üksikute liikide (V. vinifera, V. amurensis, V. riparia, Parthenocissus quinquefolia) vỗi nende sortide bioloogilisi iseärasusi omavahel.

Mikrokliima mõju tundmaõppimiseks mõõdeti vegetatsǐooniperioodil iga päev kell 9.00 kolmes erinevas kasvukohas - külmkasvuhoones, seina ääres ja avamaal - õhu temperatuur ja niiskus nädalase termo- ja hüdrograafiga ning mulla temperatuur erinevates sügavustes $(10,20,40,60 \mathrm{~cm})$ sügavtermomeetritega.

Talveperioodil mõõdeti mulla temperatuuri sügavtermomeetritega $40 \mathrm{~cm}$ sügavusel (tsoonis, kus asub peamine juurte mass). Peale selle tehti kindlaks temperatuur erinevate kattematerjalide all.

Kasvu ja arenemise iseärasuste väljaselgitamine toimus vegetatsiooniperioodil vastavalt kultuuri fenofaasidele. Liikide ja sortide fenofaasid ja nende läbimise tingimused märgiti vastavates vaatluspunktides vaatluslehtede alusel üle kogu Eesti. Tartu katsepunktides toimus võrse kasvu dünaamika mõõtmine sortidel 'Hamburgi must', 'Broadland', 'Malingre varajane', 'Alfa' ja 'Potapenko nr. 10' iga 10 päeva järel, kusjuures mõõdeti 10 vōrset igast sordist.

Fotosüntees määrati Sachsi meetodil vastavalt taime fenofaasidele, arvestades nii päevast kui ka vegetatsiooniaegset dünaamikat. Proo- 
vid võeti $0,7 \mathrm{~cm}$ läbimõõduga korgipuuriga neli korda päevas - kell $8.00,12.00,16.00$ ja 20.00 . Selleks valiti 10 lehte võrsete keskpaigast (kasvuhoones - viies, kuues, seitsmes leht; avamaal - seitsmes, kaheksas, üheksas leht). Lehed valiți võimalikult ühesugused, võrdselt valgustatud ja võrdse asetusega võrsetel. Igast lehest lõigati välja 20 ketast kokku 200 ketast ühes bioloogilises proovis, kogusuurusega $76 \mathrm{~cm}^{2}$. Orgaanilise aine juurdeteke arvutati valgustatud, äravool aga pimendatud lehtedelt.

Juurekava süg avust uuriti $20 \mathrm{~cm}$ paksuste kihtide kaupa kuni $100 \mathrm{~cm}$ sügavuseni $392,5 \mathrm{~cm}^{3}$ mahutavusega sügavmullapuuriga. Kolmel põõsal eraldati lõunapoolsel küljel $50 \mathrm{~cm}$ kaugusel põõsast $1 \mathrm{~m}^{2}$ suurused kvadraadid, millest igaüks omakorda jaotati 25 ühesuuruseks ruuduks. Igast väikesest ruudust võeti üks proov viiest eri sügavusest, seega $1 \mathrm{~m}^{3}$ suurusest maapinnast kokku 125 üksikproovi. Need rühmitati sügavuste järgi ja asetati siis pikeerimiskasti, kusjuures eraldati kohe valged tegevjuured pruunikatest juhtjuurtest. Laboratooriumis mõõdeti juurte pikkused (fraktsioonide ja sügavuste kaupa eraldi), pesti sõeltel (avade $\phi 0,25 \mathrm{~cm}$ ), kuivatati õhukuivuseni ja kaaluti analüütilistel kaaludel. Et paremini karakteriseerida tegevjuurekava, oleme tarvitusele võtnud tingliku hargnemiskoefitsiendi mõiste, s. o. tegevjuurte pikkuse suhe juhtjuurtesse.

Puitumise dün a mika määrati floroglutsiini ja soolhappega, korgistumise dü na a mika - sudaanglütseriini ja lügooli lahusega. Anatoomilised lõiked tehti habemenoaga võrse viienda ja kuuenda sõlmevahe ventraalselt poolelt. Jälgiti fellogeeni ja niinekiudude teket ning peridermi moodustumist.

Tärklisesisalduse düna amikat uuriti analoogilistes lõikudes nii tsütoloogiliselt kui ka keemiliselt: esimesel juhul 5-pallilise süsteemi järgi lügooli lahusega lõike eri osades - säsis, säsikiirtes, perimedullaarses tsoonis, ksüleemi ja floeemi parenhüümis ning koores; teisel juhul määrati tärklisesisaldus protsentides diastaasimeetodiga.

Monosahhariidide esinemine määrati Bertrandi järgi.

Klorofüllisisaldus lehtedes määrati elektrofotokolorimeetriga.

\section{Uurimistulemused}

Inventariseerimine ja aprobeerimine. Eestis on viinapuuliste sugukonnast praktilise tähtsusega perekonnad viinapuu (Vitis L.) ja metsviinapuu (Parthenocissus Planch.).

Harilikku viinapuud ( $V$. vinifera L.) kasvatatakse marjade saamiseks nii kasvuhoones (soe- ja ka külmkasvuhoones) kui ka avamaal. Kasvuhoones kasvatatakse meil järgmisi sorte: 'Hamburgi must', 'Suur Kolman', 'Alikant', 'Forsteri valge seemik', 'Leipzigi varajane', 'Portugali sinine', 'Broadland'; avamaal - 'Malingre varajane', 'Burgundia sinine', 'Triumph', 'Madeleine Angevine', 'Broadland', 'Madeleine royal'. Mõnesid-viinapuu liike kasutatakse ühtlasi dekoratiivtaimedena, näiteks amuuri viinapuud (V. amurensis Rupr.) ja kalda-viinapuud V. riparia Michx. (V. vulpina L.).

Metsviinapuu liikidest on dekoratiivtaimedena levinud viieleheline metsviinapuu (Parthenocissus quinquefolia). murorum-teisendi kujul; harvemini esineb ka teisend hirsuta.

Aastatel 1949-1957 on Eestis emataimedena arvele võetud ning tunnustatud 812 viinapuu põõsast, millest 399 kasvab avamaal, 223 seina ääres ja 190 kasvuhoones (tabel 1). 
Liigi ja sordi nimetus

\begin{tabular}{|c|c|c|c|c|c|c|c|c|c|c|c|c|c|c|c|c|c|c|c|c|c|c|c|c|c|c|c|c|}
\hline & & & & & & & & & & & & & & & & & & & & & & ende & & & & & & \\
\hline 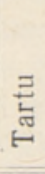 & 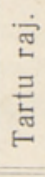 & 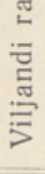 & 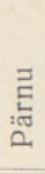 & & 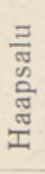 & $\frac{\pi}{\pi}$ & $\begin{array}{l}\text { : } \\
\text { : } \\
\text { L }\end{array}$ & 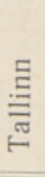 & 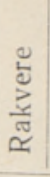 & 言 & 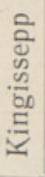 & $\frac{\overrightarrow{3}}{\frac{3}{0}}$ & 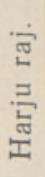 & 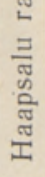 & 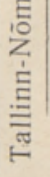 & $\begin{array}{l}\bar{\nu} \\
\frac{0}{0} \\
0 \\
0\end{array}$ & 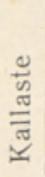 & 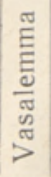 & 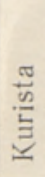 & $\frac{\pi}{\frac{\pi}{4}}$ & 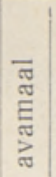 & 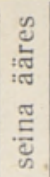 & 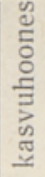 & $\begin{array}{l}\frac{\bar{v}}{y} \\
\frac{\overrightarrow{0}}{0}\end{array}$ & 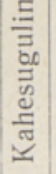 & 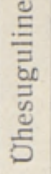 & 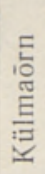 & $\stackrel{\text { ले }}{\equiv}$ \\
\hline
\end{tabular}

Vitis vinifera

Malingre varajane

Madeleine royal

Madeleine Angevine

Triumph

Broadland

Valge õilismari

Hamburgi must

Suur Kolman

Forsteri valge seemik

Aleksandri muskaat

Alikant

Malingre seemik

Must magus

Vitis Labrusca

Vene Konkord

Vitis riparia

Alía

25

Vitis amurensis

Buitur

Potapenko nr. 10

Vitis amurensis

Parthenocissus

Parthenoc. quinquefolia var. murorum

Parthenoc, quinquefolia var. hirsute

14

25

11

C3

7

$-$

3

7

4

13

7

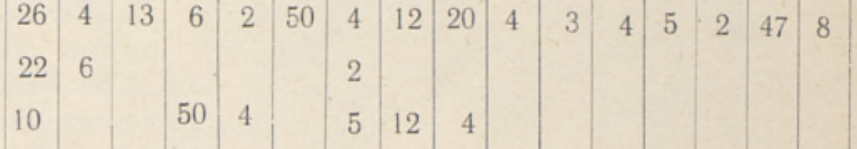

4

\begin{tabular}{l}
8 \\
\hline
\end{tabular}

Esineb kõikjal Eesti NSV-s

5

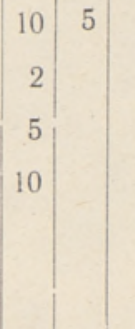

1224

\begin{tabular}{l|l|l}
8 & 3 & 52
\end{tabular}
10

$31084139-223+$

$30 \quad 30+$

$60 \quad 35$

$\begin{array}{ll}68 & 14\end{array}$

$5611+$

$\begin{array}{ll}7 & 2\end{array}$

27

\begin{tabular}{l|l}
7 \\
$-\quad 133$
\end{tabular}

$128128+$

$99+$

$99+$

$1010+$

$33+$

7

13

7

$13+$

4

$133+$

Esineb harva

Kokku

\begin{tabular}{|l|l|l|l|l|l|l|l|l|l|l|l|l|l|l|l|l|l|l|l|l|l|l|l|l|}
264 & 10 & 21 & 120 & 15 & 50 & 11 & 61 & 37 & 4 & 18 & 80 & 5 & 2 & 47 & 8 & 37 & 7 & 2 & 3 & 10 & 399 & 223 & 190 & 812 \\
\hline
\end{tabular}


Viinapuu nõudlustest välistingimuste suhtes. Peamised klimaatilised tegurid, mis määravad viinapuukultuuri leviku, on temperatuur, päikesepaiste, niiskus ja külmavaba perioodi kestus.

Negruli (1956) andmetel algab viinapuu pungade puhkemine siis, kui öö-päeva keskmine temperatuur on $+10 \mathrm{kuni}+12^{\circ} \mathrm{C}$. Temperatuur alla $+14^{\circ} \mathrm{C}$ takistab ōitsemist. Parimaks relatiivseks ōhuniiskuseks on 70 $80 \%$. Lazarise (1952) järgi nõuavad väga varajased sordid pungade puhkemisest kuni marjade valmimiseni, 110-120 päeva jooksul, kogusummas $2200-2400^{\circ} \mathrm{C}$ aktiivset temperatuuri. Vogt (1951) konstateerib, et viinapuukasvatuse rajoonis peaks aastas keskmine õhu temperatuur olema vähemalt $+9^{\circ} \mathrm{C}$, sademeid $500-600 \mathrm{~mm}$ ja päikesepaiste kestus vähemalt 1300 tundi. (Keskmine päikesepaiste kestus aastas on Saksa- ja Prantsusmaal 1600, Krimmis 2400 ja Eestis 1700 tundi.)

Klimaatiliselt kuulub Eesti üleminekupiirkonda Euroopa läänepoolsest maritiimse kliima valdkonnast Ida-Euroopa valdkonda (Kirde, 1939). Tartu meteoroloogiajaama andmetel kõikus Eestis aasta keskmine õhu $\mathrm{t}^{\mathrm{C}}$ ajavahemikul $1900-1950+2,8$ kuni $+6,8^{\circ} \mathrm{C}$ piirides, päikesepaisteliste tundide arv aastatel 1910-1950 oli 1246-2053 ja keskmine sademete hulk 1926.-1946. aastani oli $587 \mathrm{~mm}$. Keskmise õhutemperatuuriga üle $+10^{\circ} \mathrm{C}$ päevi ajavahemikul 12. V 1881 - 20. IX 1935 oli 130.

Esitatud näitajate järgi paistab Eesti mandri kliima viinapuukasvałusele olevat üldiselt soodus. Vajaka jääb aga aktiivsete temperatuuride osas. Takistavat mōju avaldavad ka hilised kevadised ja varajased sügisesed öökülmad.

Arvestades eespool öeldut tuleb soojusrežiimi suurendamiseks kasutada kōiki mikroklimaatilisi vōtteid, nagu kaitseistandusi, kulisse, tarasid, majade seinu ja klaasialust (vt. joon. 1).

Nagu jooniselt 1 näha, on avamaal aktiivsete temperatuuride summa ca $20 \%$ väiksem kui seina ääres ja ca $44 \%$ väiksem kui klaasi all. Vegetatsiooniaja pikkus aga oleneb peale aktiivsete temperatuuride summa veel päikesepaisteliste tundide arvust. Kevadistest hilistest öökülmadest tingitud kahjustuste ärahoidmiseks on vaja avada taimed hiljem või teha suitsukatet. Vegetatsiooniperioodi lühendamiseks tuleb kasutada agrotehnilisi võtteid, nagu õige! sortide ja maapinna valikut ja viljakandvate ning asendusvōrsete näpistamist.

Kui võrrelda vegetatsiooniperioodi pikkust (päevade arv keskmise ōhutemperatuuriga üle $+10^{\circ} \mathrm{C}$, s. o. bioloogilise nulli)

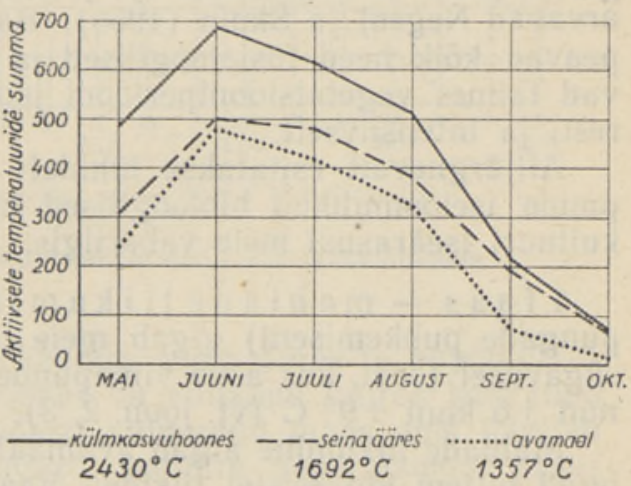

Joon. 1. Aktiivsete temperatuuride summa erinevates kasvukohtades aastal 1956. Eesti mandril (Tartu meteoroloogiajaama andmed ajavahemikus 1891-1935) ja saartel (Kingissepa meteoroloogiajaama andmed samal ajavahemikul), siis ilmneb, et see on saartel 2 päeva lühem kui mandril: Tartus 130 (12. V - 20. IX) ja Kingissepas 128 (20. V - 26. IX) päeva. Võrreldes aga külmavaba perioodi pikkust vegetatsiooniajal, on see saartel ümberkaudu 29 päeva pikem: Tartus keskmiselt 150 (7. V - 5. X), Kingissepas aga 179 (26. IV - 23. X) päeva. Viimane asjaolu etendab väga suurt tähtsust viinapuukasvatuses, sest pikk külmavaba periood, eriti sügisel, soodustab võrsete 
valmimist, karastumisfaasi läbimist ja tõstab võrse talvekindlust. Selle aja jooksul jõuavad Saaremaa oludes viinapuu võrsetes lõpuni kulgeda nii anatoomilis-struktuursed kui ka füsioloogilis-biokeemilised muutused, mis seevastu mandril, näiteks Tartu tingimustes, esimeste varajaste sügiseste öökülmadega katkestatakse. Sellepärast kulgebki viimane, s. o. lehtede langemise faas saartel normaalselt. Mille muuga on võimalik seletada fakti, et asjaarmastaja viinapuukasvataja sm. Priske kasvatab Kingissepas mitmeid aastaid viinapuid ja saab neilt suuri saake, ilma et ta neid pärast mahapainutamist talveks kinni kataks.

1955/56. a. pakasel talvel hävis Saaremaal hulgaliselt viljapuid, sest temperatuur lumepinnal langes kuni $-32^{\circ} \mathrm{C}$. Viinapuud aga $18 \mathrm{~cm}$ paksuse lumekatte all säilisid tervena ja andsid järgmisel aastal normaalselt saaki (10-20 kg põõsalt).

Sellest võib teha järgmised järeldused:

1. Hästi valminud viinapuuvõrse on küllaltki külmakindel ja suurte pakaste puhul talvitub lumekatte all kahjustamatult katmata olekus.

2. Bioloogiline null $+10^{\circ} \mathrm{C}$ ei ole mingi absoluutne viinapuu elutegevuse näitaja, vaid viinapuus toimuvad võrdlemisi intensiivsed ainevahetus. protsessid ka madalamate keskmiste ööpäeva temperatuuride juures, eriti sügisel võrsete valmimise faasis. Seega vajavad korrigeerimist ka senini kehtestatud aktiivsete temperatuuride summad selle kultuuri jaoks.

3. Arvestades Eesti NSV küllaltki väikese territooriumi ulatuses mikrokliimat, on kõige sobivam viinapuid välistingimustes kasvatada saartel ja Lääne-Eestis; seinaäärse ja katmikkultuurina kasvab viinapuu kõikjal Eestis, kusjuures valmivad nii tema võrsed kui ka marjad.

Viinapuu kasvamise ja arenemise iseärasusi Eestis. Viinapuu vegetatsiooniperiood põhja oludes algab hiljem ja lõpeb varem kui lõunas; seepärast peab ta lühendatud aja jooksul läbi tegema kõik fenofaasid. Nagu arvavad Negrul ja Skuin (1955), Baranov (1946) ja Pētersons (1953), peavad kõik need füsioloogilised ja biokeemilised protsessid, mis toimuvad taimes vegetatsiooniperioodi jooksul, kulgema viinapuul põhjas kiiresti ja intensiivselt.

Alljärgnevalt esitatakse lühidalt fenofaaside kaupa mõningad viinapuude iseloomulikud bioloogilised näitajad, mis aitavad selgitada selle kultuuri iseärasusi meie vabariigis.

I f a a - ma hla de $1 \mathrm{i}$ i kumine (mahlade liikumise algusest kuni pungade puhkemiseni) algab meie tingimustes siis, kui mulla $\mathrm{t}^{\circ} 40 \mathrm{~cm}$ sügavusel (seal, kus asub viinapuude peamine juurte mass)* on saavutanud +6 kuni $+9^{\circ} \mathrm{C}$ (vt. joon. 2,3 ).

Mahlade liikumine algab avamaal mai esimesel dekaadil - V. vinifera'l hiljem kui teistel liikidel. Vaatlused aastate jooksul (1891-1935) näitavad, et Tartus on viimased hilised kevadised öökülmad esinenud 7 . mail, erandjuhtudel 8. juunil. 1957. aastal kahjustas viimane öökülm viinapuude üheaastasi võrseid 27. mail.

Selleks et vältida kevadiste hiliste öökülmade kahjustusi, on võimalik

* Tugeva juurekavaga sordi 'Alfa' peamine tegevjuurestik asub liivsavimullal 20$40 \mathrm{~cm}$ sügavusel (hargnemiskoefitsient 1,52), saviliivmullal aga $40-60 \mathrm{~cm}$ sügavusel (hargnemiskoefitsient 1,09) (joon. 4). 'Malingre varajasel' kui nõrga juurekavaga sordil on peamine tegevjuurestik $0-20 \mathrm{~cm}$ sügavusel (hargnemiskoefitsient 2,54). Sellest järeldub, et maapind tuleb ette valmistada vähemalt $60 \mathrm{~cm}$ sügavuselt, nii et tegevjuured vōiksid moodustuda $40-60 \mathrm{~cm}$ sügavusel ja oleksid kaitstud pakase eest.

Juhtjuured asuvad peamiselt $40-60 \mathrm{~cm}$ sügavusel kōikides mullaliikides, välja arvatud toitainetevaesed liivmullad. 
kõnealust faasi talvkatte all, s. o. lume pealekogumisega, pikendada. Võib teha ka suitsukatet. Et takistada mahlade liigset kadu I faasis, ei tohi tugeva juurerõhu tõttu teostada viinapuu lõikusi. Meie katsed näitavad, et viinapuu juured taluvad maapinnas täiesti kuni $-5^{\circ} \mathrm{C}$ ja hästi puitunud võrsed kuni $-20^{\circ} \mathrm{C}$.

II faas - pungade puhkemine ja võrsete kas v kuni õitsemise a $1 \mathrm{guseni}$. See faas algab õhu temperatuuril +10 kuni $+12^{\circ} \mathrm{C}$ ja mulla temperatuuril paari kraadi võrra madalamal (vt. joon. 2, 3). Ajaliselt langeb pungade puhkemine külmkasvuhoones mai

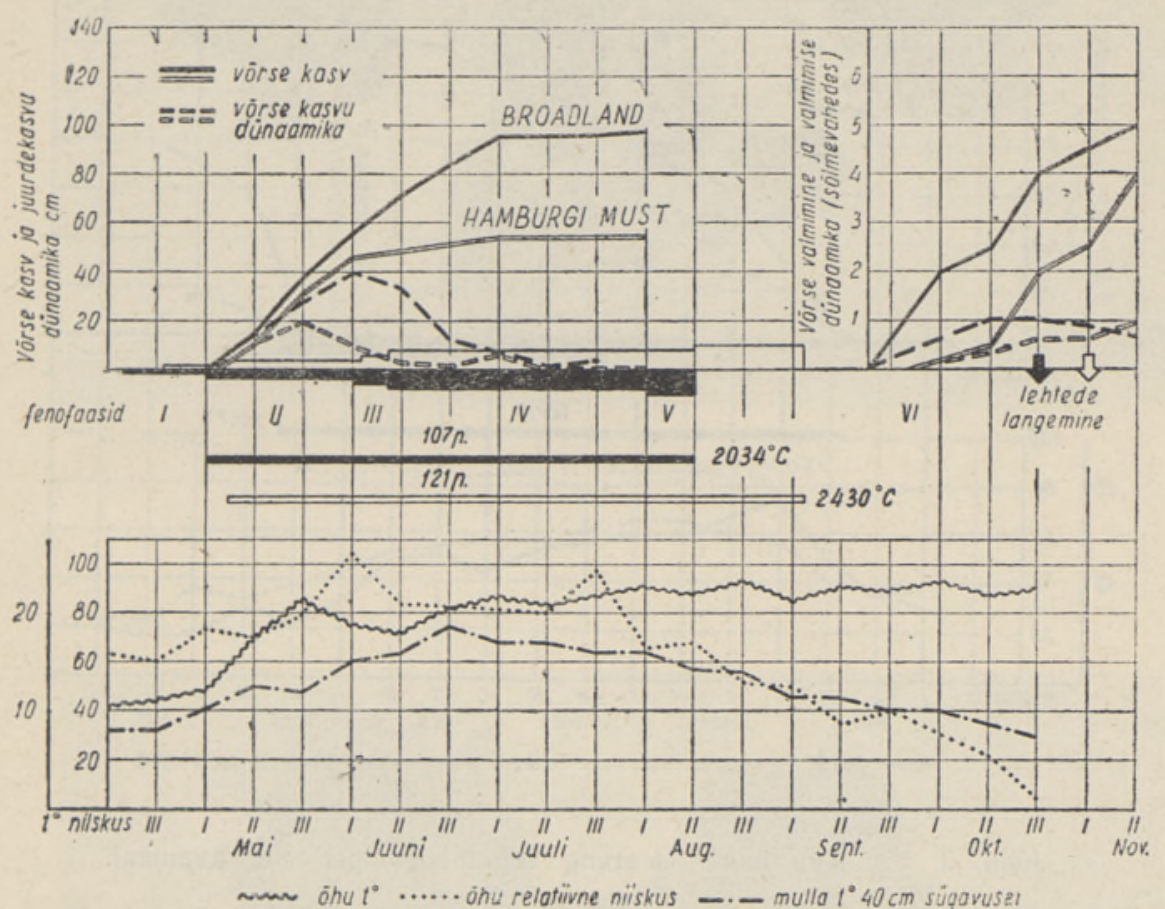

Joon. 2. Viinapuu kasv ja areng vegetatsiooniperioodil külmkasvuhoones.

esimesele, vahel ka aprilli viimasele dekaadile, seina ääres ja avamaal mai viimasele dekaadile. Külmkasvuhoones on viinapuu juured kasvanud seina alt välja, kus nad asuvad sagedasti külmanud maas, mis hävitab tegevjuured ja takistab juhtjuurte tegevust. Seetõttu vegetatsiooni algus viibib. Sellepärast on vaja külmkasvuhoonete ümbrus nii nagu avamaalgi katta 2-4 m ulatuses orgaanilise materjaliga. Uute külmkasvuhoonete rajamisel tuleb lasta viinapuu juured kasvada kasvuhoone keskele, kus toimuks ka väetamine ja talvel oleksid juured kaitstud.

Mittelahustuvad orgaanilised ained (tärklis) muutuvad selles faasis lahustuvaiks (suhkur) ja tungivad kasvupunkti, kutsudes esile võrse algmete kasvu (vt. joon. 2, 3). Algul kasvavad võrsed pikkamööda, hiljem väga intensiivselt ja omandavad kõnesoleval faasil ligi $50-60 \%$ oma täielikust pikkusest.

Mulla $\mathrm{t}^{\circ}$ tõuseb $30-40 \mathrm{~cm}$ sügavusel +15 kraadini, mis kutsub esile tegevjuurte moodustumise. Uhtlasi algab kõikide organite normaalne elutegevus. 
Teiskasvu võib märgata viiendal sõlmevahel 10.-15. päeval pärast pungade puhkemist (mikrofotod I ja II).

Kambiumi tegevus viiendal sõlmevahel algab kõige varem $V$. amurensis'el -8 päeva, kõige hiljem $V$. vinifera'l - 15 päeva pärast pungade puhkemist. Sel perioodil on võrse niiskussisaldus kõrgeim (80$86 \%)$. Monosahhariididesisaldus on võrdlemisi suur $(5 \%)$, tärkliseprotsent aga väike $(1,3 \%)$. Tärklis tekib esmalt peritsükli kiudkimpude ümber suurte teradena ja esikoores. Võrse noored koore rakud sisaldavad kloroplaste ja on võimelised fotosünteesima.

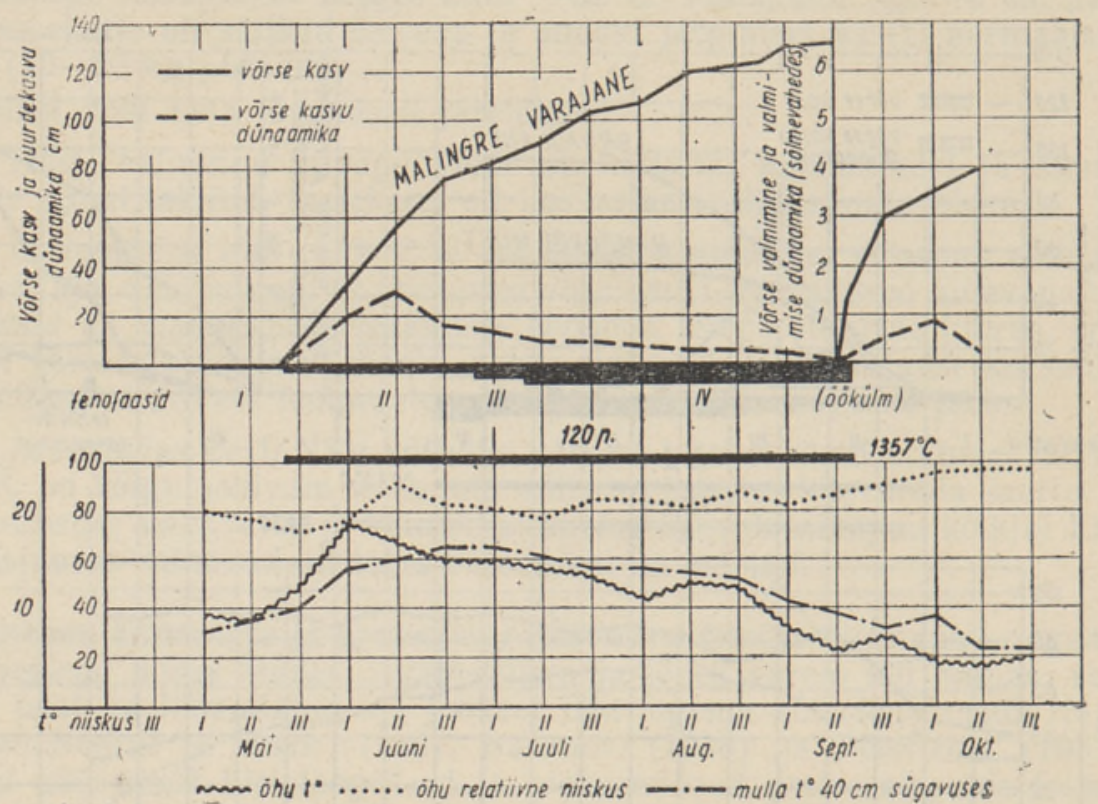

Joon. 3. Viinapuu kasv ja areng vegetatsiooniperioodil ayamaal.

Selle faasi pikkus oleneb sortide iseloomust, kasvukohast ja välistingimustest. Külmkasvuhoones kestab see 30 , avamaal ja seina ääres 35-40 päeva. Nõukogude Liidu lõunarajoonides kestab see faas avamaal $40-45$ рӓеva (Негруль, 1956).

III fa as - õits emine. Selle kulg oleneb ilmastikust. Eestis kasvavad kahesugulised viinapuud viljastuvad peaaegu alati sajaprotsendiliselt, vaatamata halbadele ilmastikuoludele. Viimased ainult pikendavad faasi pikkust. Uhesugulised sordid, mis nõuavad tolmeldajaid sorte (näit. 'Madeleine Angevine', 'Malingre seemik', 'Potapenko nr. 10' jt.), ei tolmle hästi ja neid on vaja kunstlikult tolmelda.

Oitsemine kestab meie tingimustes 5-12 päeva. Kõige enne hakkab oitsema kobara alumine, siis ülemine osa. Nagu meie katsed näitavad, on üheaegseks õitsemiseks ja marjade valmimiseks soovitav kobara latva kärpida, ühtlasi nädal võ̃i paar enne õitsemist pintseerida viljakandev võrse. Sellega me peatame võrse kasvuprotsessi ja suuname kõik plastilised ained öitsemise kiirendamiseks ning paremaks viljumiseks.

Kõnealusel faasil hakkab võrse juurdekasv vähenema. Lõpeb interkalaarne kasv. Võrse jämeneb. Sel vegetatsiooniperioodi faasil sisaldab 


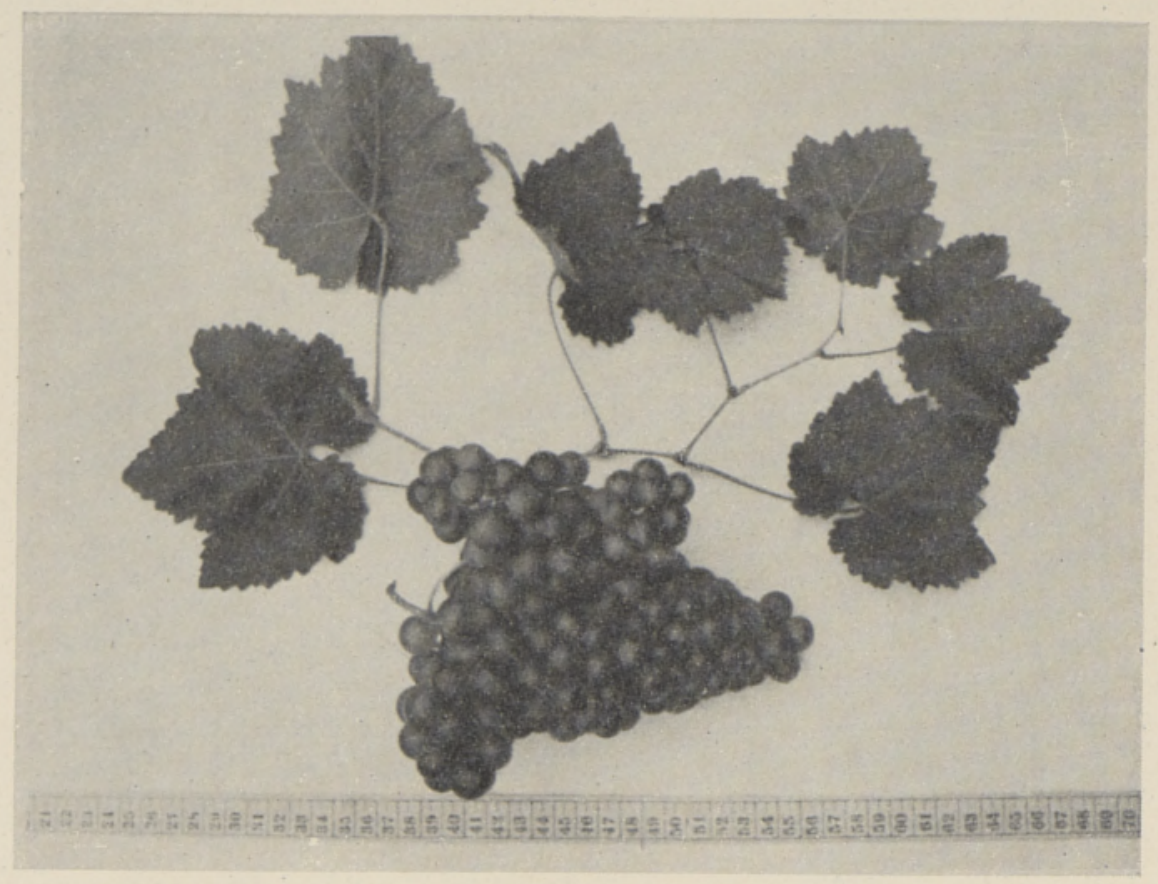

Foto 1. 'Hamburgi must'

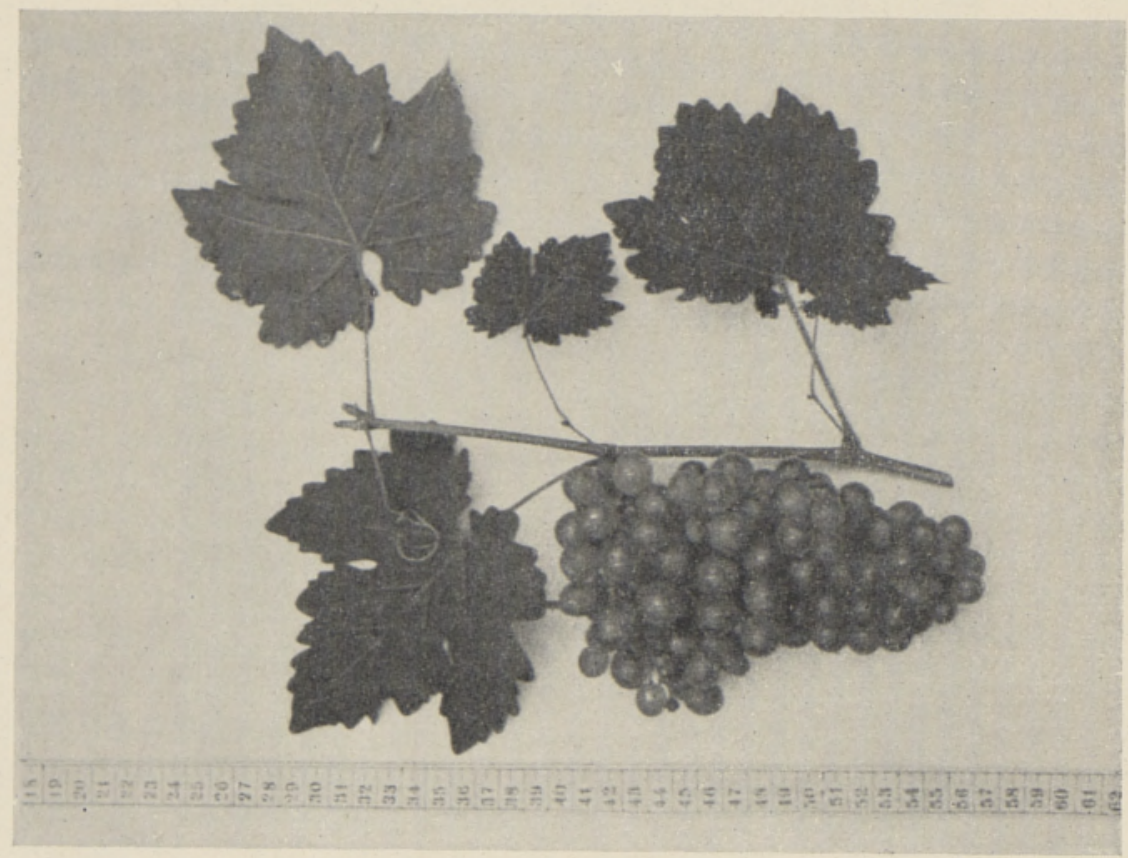

Foto 2. 'Malingre varajane' 


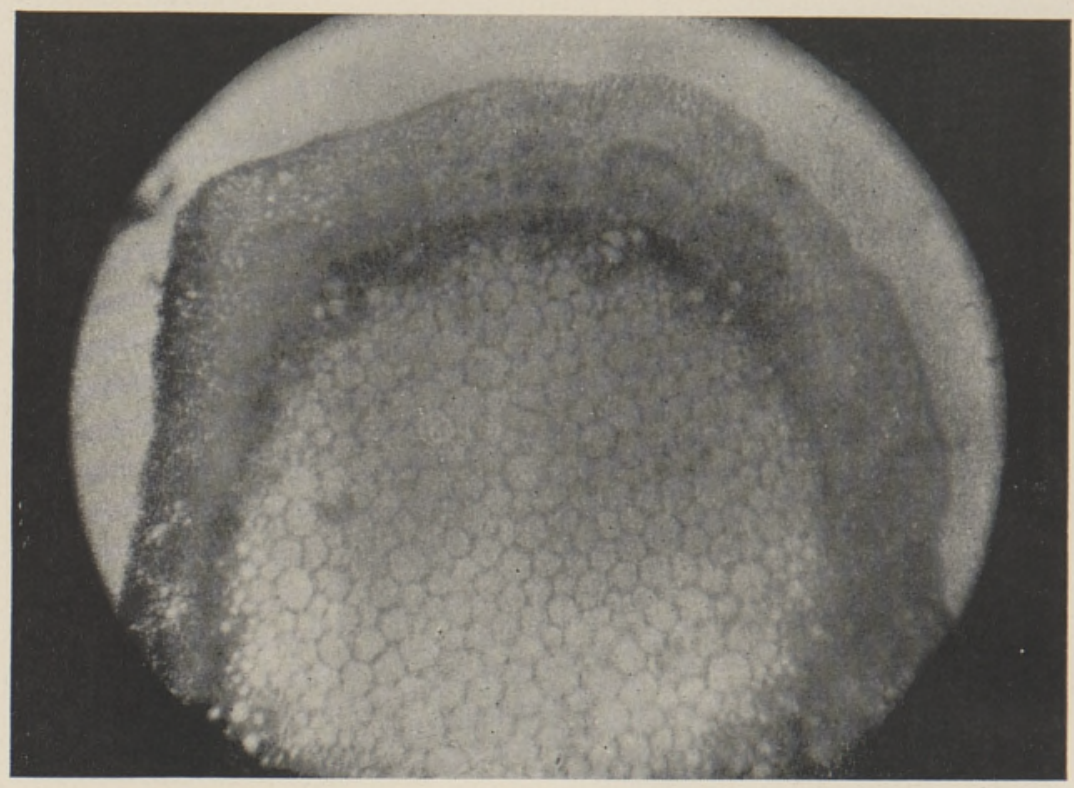

Mikrofoto I. Vitis amurensis'e esikasv. (Suurend. $5 \times 8$.)

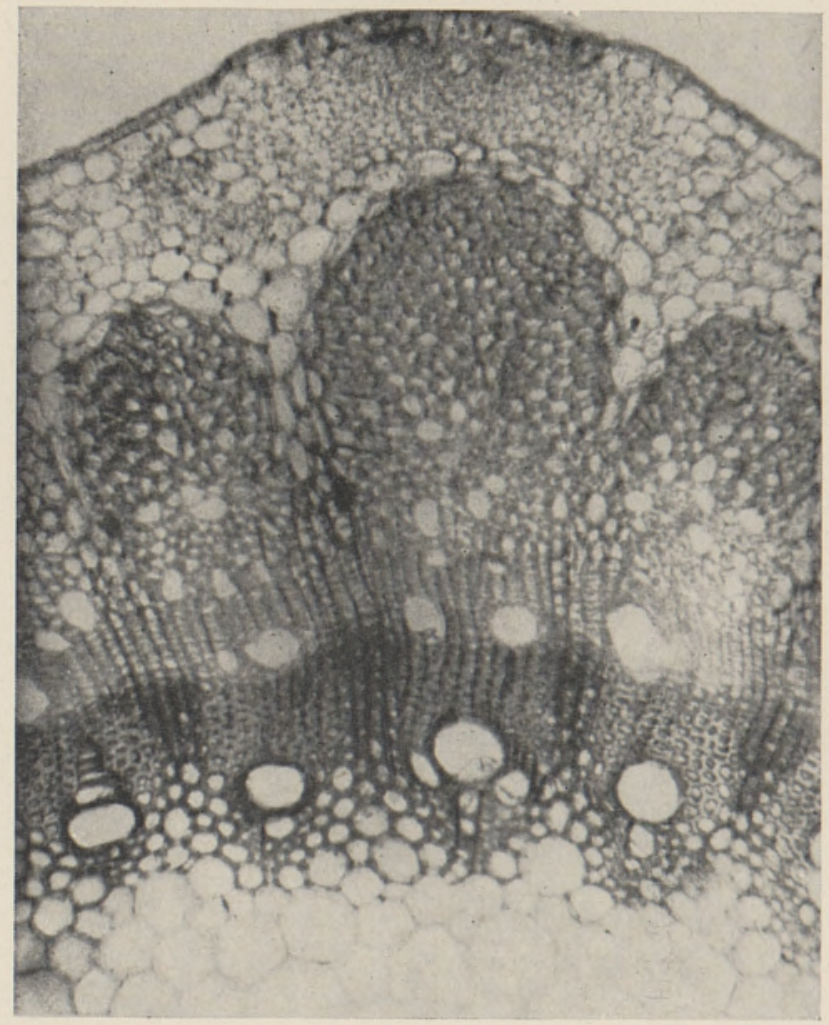

Mikrofoto II. Vitis amurensis'e teiskasv. (Suurend. $15 \times 8$.) 
võrse maksimaalselt suhkrut $(5-6 \%)$ ja minimaalselt tärklist $(0,3-$ $1,5 \%)$. Viimased näitajad olenevad liigist ja vōrse asukohast põõsal.

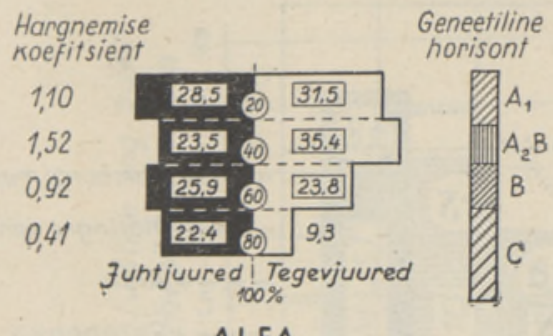

TARTU - KESKMINE LIIVSAVI

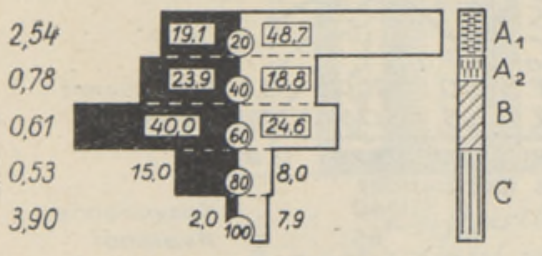

MALINGRE VARAJANE RATPINA - KERGE SAVILIIV
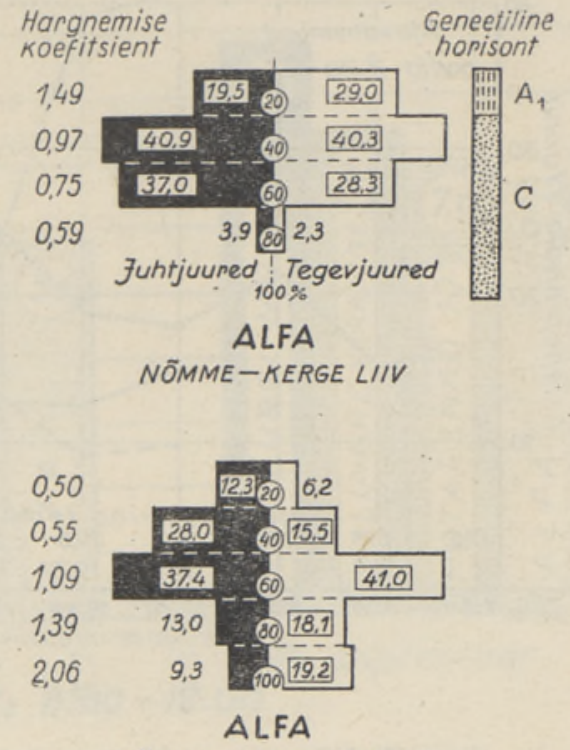

RÄPINA - KERGE SAVILIIV

Joon. 4. Viinapuude juht- ja tegevjuured (protsentides) mulla erinevates sügavustes.

Viinapuu elutegevus sellel faasil on väga intensiivne. Nagu näitavad Aleksandrovi jt. (1929) andmed, koguvad viinapuud sellal orgaanilist ainet $11,5-18,0 \mathrm{mg} 1 \mathrm{dm}^{2}$ lehepinna kohta tunnis. Vassiljeva (1956) andmetel Moskva oblastist fotosünteesivad viinapuud 14,2-18,8 $\mathrm{mg}$ kuivainet $1 \mathrm{dm}^{2}$ lehepinna kohta tunnis. Meil kasvatatavad viinapuud assimileerivad intensiivsemalt kui lõunas kasvavad ja seda kõikides fenofaasides, kusjuures püsib kõrge fotosünteesi intensiivsus ka sügiskuudel (joon. 5).

Vastavalt kirjanduse andmetele (Рубин, 1949) on fotosünteesi dünaamika taimedel kindlaks liigi tunnuseks ka siis, kui taimed on juba pikka aega viibinud ebasoodsates välistingimustes.

Joonisel 5 näeme, et sorti 'Potapenko nr. 10', millel on ülekaalus amuuri viinapuu tunnused, karakteriseerib vegetatsiooni esimesel poolel kõrge fotosünteesi intensiivsus, võrreldes $V$. vinifera'ga ('Malingre varajane'). Vegetatsiooni lõpu poole $V$. amurensis'e fotosünteesi intensiivsus langeb, mis on iseloomulik sellele viinapuu liigile, sest amuuri viinapuu lõpetab oma kasvu varem kui teised katses olevad liigid. V. vinifera'l püsib kõrge fotosünteesi intensiivsus kuni esimeste öökülmadeni, olles kasvu mittelõpetamise tunnuseks. Sedasama näitab klorofülli hulga dünaamika (joon 6).

Arvatavasti avaldab siin omajagu mõju ka päeva lühenemine, sest amuuri viinapuu ja tema hübriidid assimileerivad antud juhul halvemini kui pika päeva tingimustes (Потапенко, Захарова, 1937).

Mis puutub teiste välistingimuste toimesse, siis temperatuuri langemisel fotosüntees ei katke. Seda kinnitavad ka kirjanduse andmed (Басанько, 1953), mis näitavad, et oktoobrikuus $+6,7^{\circ} \mathrm{C}$ temperatuuril on viinapuudel fotosüntees võrdne septembrikuuga, temperatuuril $+11^{\circ} \mathrm{C}$. 
Küll näib meie katsetes enam mõju avaldavat valguse tugevus, mille vähenedes väheneb ka fotosüntees. Samuti mōjub assimilatsioonile negatiivselt niiskuse puudus.

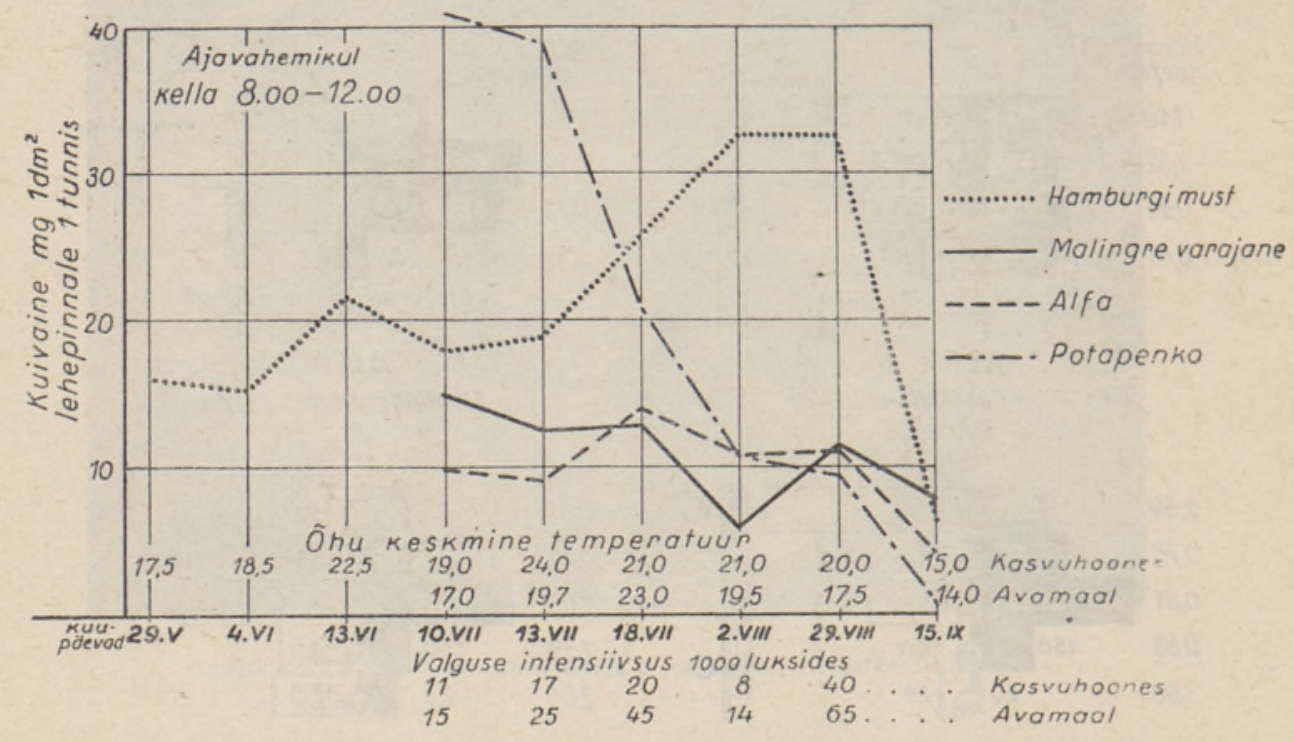

Joorr. 5. Viinapuu sortide fotosünteesi intensiivsus vegetatsiooniperioodil.

Mis puutub klaasialusesse sordisse 'Hamburgi must', siis on siin fotosüntees kogu vegetatsiooniperioodil väga kōrge, eriti intensiivne aga marjade kasvu faasil. Nimetatud sordi kõrget fotosünteesivöimet võib seletada suurema klorofüllihulgaga kui teistel sortidel. Viimane on ka üheks suure saagikuse näitajaks, sest katseaastatel kandsid põõsad väga rikkalikuli vilja. Sort näib olevat kohanenud nōrgemate valgustingimustega, sest 8000 luksi juures on fotosüntees kasvuhoones $32 \mathrm{mg}$ kuivainet $1 \mathrm{dm}^{2}$ lehepinnale tunnis, samal ajal 14000 luksi puhul avamaal aga $7-11 \mathrm{mg}$.

IV f a a s - marja de kasvamine (õitsemise lõpust kuni marjade valmimise alguseni). Vegetatiivne kasv väheneb vôi lõpeb hoopis (kasvuhoone-sortidel). Faasi võib jaotada kahte ossa. Esimesel poolel toimub intensiivne võrsete kasv ja jämenemine. Teisel poolel väheneb kambiumi tegevus (hiljem lakkab hoopis), produtseerides elemente enam niinossa. Tekivad niinekiud ja augusti teisel poolel võib $V$. amurensis'el märgata juba fellogeeni moodustumist. V. vinifera esindajal 'Malingre varajasel' tekivad niinekiud varem kui $V$. amurensis'el ja neiđ on esimesel rohkem kui teisel. $V$. amurensis'el on niinekiud nõrgemini välja arenenud selle tõttu, et ta kasvab väga intensiivselt pikkusesse. Uldiselt puitub $V$. vinifera halvemini kui $V$. amurensis. Sellepärast ei saa niinekiudude rohkust pidada atseseks puitumise näitajaks. 'Malingre varajasel' tekib fellogeen hiljem.

Ka tagavaraainete talletamine algab $V$. amurensis'el varem kui 'Malingre varajasel'; samuti on võrsete valmimise protsess esimesel parem kui teisel. Tärklis hakkab kogunema puidu säsikiirte säsipoolsesse otsa ja perimedullaarsesse tsooni. Uksikud tärklisterad kogunevad ka ksü'eemi parenhüümi. Algab.võrsete valmimine. Sel ajal tõuseb tärklise ja väheneb suhkru hulk. Hiljem puitub floeem ja kõige hiljem kambium, sest siia ladestub tärklis kõige hiljem.

Sel perioodil (meil kulgeb ta augusti viimasel dekaadil) tuleb võrsete 
valmimise kiirendamiseks kasutada agrotehnilisi võtteid. Parimaid tulemusi meie katsetes on andnud võrse ladva näpistamine kümnendalt ja ennakvõrsete näpistamine neljandalt lehelt.

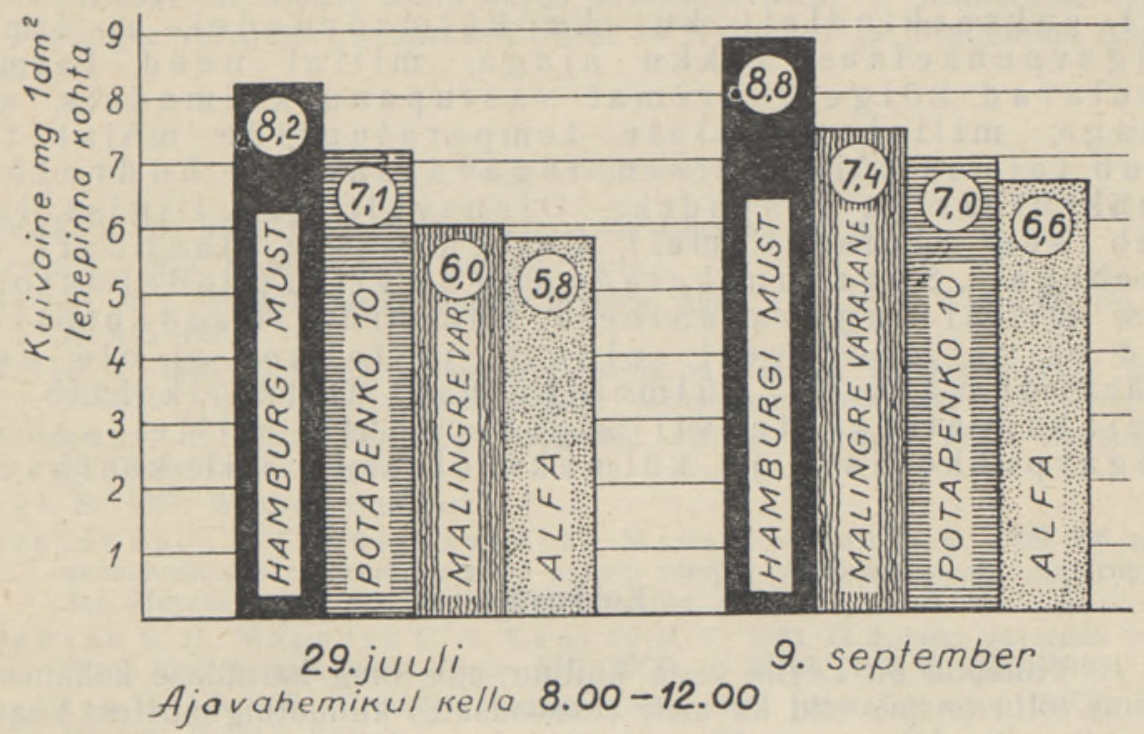

Joon. 6. Viinapuude klorofüllisisaldus 1957. a.

$\mathrm{V}$ faas - marjade valmimine (valmimise algusest kuni täisküpsuseni). Mari saab oma värvuse. Eestis valmivad kasvuhoone-sordid augustis-septembris, seina ääres ja avamaal septembris-oktoobris. Vôrsete ja marjade valmimine ei lange alati kokku. Amuuri viinapuu tüüpilistel sortidel algab võrsete valmimine meie tingimustes varem kui marjade valmimine, $V$. vinifera sortidel aga viljade valmimise ajal vōi veel hiljem. Viimasel juhul jäävad taimed sagedasti varajaste öökülmade kätte ja kannatavad nende all. Tartu oludes algavad varajased öökülmad (aastate 1891-1935 andmeil) sügisel 5. oktoobril, erandjuhtudel 6. septembril ja kōige hiljem 24. oktoobril.

$1-2{ }^{\circ} \mathrm{C}$ öökülm ei tee marjadele nende kõrge suhkrusisalduse tõttu märkimisväärset kahju. Suuremad öökülmad seevastu on hädaohtlikud nii marjadele kui ka halvasti valminud võrsetele. Sellepärast on meie oludes vaja tarvitusele võtta eespool nimetatud vegetatsiooniperioodi lühendamise võtted, nagu võrsete näpistamine ja maapinna mittekobestamine. Maad ei tohi kunstlikult niisutada, sest isegi sajune sügisene ilmastik ja vähene päikesepaiste pidurdavad marjade ja vôrsete valmimist.

Tavaliselt eraldatakse puittaimedel veel kuuendat faasi - võrsete valmimist, karastumist ja lehtede langemist (Домбковская, 1953; Brock, 1949; Manuel, 1955). Kõikide meil avamaal kasvatatavate viinapuu liikide juures ei saa seda faasi selgesti eraldada, sest esimesed varajased öökülmad sunnivad lehtede tegevuse lõpetama, kusjuures halvasti karastatud võrsed satuvad külma kätte. Mida valminum on võrse, seda külmakindlam ta on. Võrse valmimist ja karastumist peetakse seda intensiivsemaks, mida varem on taim puhkeperioodi läinud; ühtlasi hinnatakse taime seda külmakindlamaks (Окнина, Кузьмин, 1955).

Sergejev (1953, 1956), Afrikjan jt. (1954), Kokin ja Vilkova (1955), Henckel ja Oknina (1954) on teinud oma töödes järelduse, et puittaimedel 
valitseb tihe seos sügavpuhkefaasi ja külmakindluse vahel: kui taim asub sügavpuhkefaasis, on ta kõige külmakindlam. Et see probleem nõuab omaette käsitelu, siis piirdume siin ainult konstateerimisega, mis tuleneb meie katsetest, nimelt - et meil kasvatatavatel viinapuudel, ni pakasekindlail kui ka külmaõrnadel, ei lange sügavpuhkefaas kokku ajaga, millal need taimed osutavad kõige suuremat vastupanu külmadele, s. o. ajaga, millal madalate temperatuuride mojul toimub taimes kõige järsem tagavaraainete hüdrolüüs suhkruteks ja rasvadeks. Olenevalt puu liigist langeb see protsess meil detsembrisse, jaanuari ja veebruari. Sügavpuhkefaas aga onviinapudelok toobris, millal tagavaraainete hüdrolüütilised protsessid ei väljendu vẻel selgesti ja taimel ei ole veel märkimisvä ärset külmakindlust. Öeldu kehtib ka meil kasvatatavate viljapuude kohta, millel samuti sügavpuhkefaas ja külmakindlus ei käi käsikäes.

\section{Kokkuvõte}

1. Viinapuu on Eestis vana kultuur, mis oma haruldase kohanemisvõime tõttu on püsinud ka meie ebasoodsates kliimatingimustes. Vegetatiivselt paljundatuna on säilinud siiski tema fülogeneetilised omadused, mispärast ta lounamaise soojalembese lühipäevataimena halvasti valmib põhja pika päeva tingimustes.

2. Võrreldes põhjas kasvavat viinapuud lõunas kasvavaga, on esimesel kõik fenofaasid vegetatsiooniperioodi vältel selgesti konstateeritavad. Nendes toimuvad bioloogilised protsessid sama intensiivselt või intensiivsemaltki kui lõunas, välja arvatud viimane faas, mis ei kulge normaalselt lühikese vegetatsiooniperioodi tõttu meie tingimustes. Küll areneb ta aga normaalselt saartel ja mandri läänerannikul. See fakt loob eeldused viinapuukultuuri kasvatamiseks sealsetes tingimustes.

3. Viimase fenofaasi puuduliku kulgemise tõttu mandril jääb ka võrsete valmivus seal puudulikuks, mis avaldab mõju taime talvekindlusele.

4. Sobivate sortide valiku, mikrokliima ja agrotehniliste võtetega on võimalik kiirendada võrsete ja marjade valmimist.

5. Võrse valmivuse aste, mis väljendub tema puitumises ja korgistumises, tagab tema talvekindluse.

6. Tärklise ladestumise intensiivsusest oleneb võrse valmimine.

7. Tärkliseprotsent võrse valmimisel tõuseb, suhkruprotsent väheneb.

8. Meil oleneb viinapuu juurekava sügavus mullastikust ja viinapuu liigist. Ettevalmistamata maas asub juurte peamine mass $20-40 \mathrm{~cm}$ sügavusel. Külmakahjustuste vältimiseks tuleb viinapuu istutada $60 \mathrm{~cm}$ sügavuselt ettevalmistatud maasse. Lumeta talvedel tuleb maapind katta orgaanilise materjaliga, nii et temperatuur massilises juurte tsoonis ei langeks alla $-5^{\circ} \mathrm{C}$.

9. Fotosünteesi intensiivsuse dünaamika oleneb viinapuu liigist ja on üheks aklimatiseerumisastme näitajaks.

10. Pakasekindlamaid viinapuulisi on Parthenocissus quinquefolia var. murorum, V. amurensis ja 'Buitur'.

Suhteliselt pakasekindlad on $V$. riparia ja $V$. amurensis'e-tüübilised sordid, nagu 'Alfa' ja 'Potapenko nr. 10'. 
$V$. vinifera sordid on suhteliselt külmaõrnad ja vajavad talveks mahapainutamist ning kerget katet.

11. Parimad külmkasvuhoone-sordid on 'Broadland', 'Hamburgi must' ja 'Aleksandri muskaat', seina ääres kasvatatavatest - 'Madeleine royal' ja 'Malingre varajane', avamaasortidest - 'Triumph' ja 'Madeleine Angevine'.

\section{K I R J A N D US}

B r ock, R. B., 1949. Outdoor Grapes in Cold Climates. Kent.

Kir d e, K., 1939. Andmeid Eesti kliimast. Tartu.

M a nu e 1, H. L., 1955. Bordelais Spalier Pruning. Agric. Gaz. N. S. Wales, 66, No. 12, lk. $645-648$.

Mätlik, A., 1946. Viinapuukasvatus vabas maas on võimalik. Lühikokkuvõtteid Tartu Riikliku Olikooli põllumajanduslikkude katsejaamade töötulemustest. Tartu.

Pẽtersons, E., 1953. Brīydabs vīnogulāju šķirnes Latvijas PSR. Augḷkopība un Dārzeņkopība. Rìgā.

Vog t, E., 1951. Weinbau. Stuttgart.

Александ ров В. Г., Аб есадзе К. Ю., Мак аревская Е. А., 1929. Об ассимилящионной и транспирационной работе листьев основных кахетинских сортов. Зап. Научно-прикл. отд. Тифлисск. бот. сада, вып, VI.

А фр и кян Б. Л., М а р у т я С. А., С а а к ян Р. Т., 1954. О формах запасных углеводов виноградной лозы. Докл. АН CCCP, т. XCVI, № 6, lk. 1195-1196.

Б ар анов П. А., 1946. Строение виноградной лозы. Ампелография СССР, т. I. Москва, Ik. 217-230.

Ба с анько А. А., Т ур жов а М. П., 1953. Определение сроков обрезки с учетом ассимиляционной деятельности листьев. Виноделие и виноградарство, № 6 .

В а с и л ь е в а 3. В., 1956. Фотосинтез некоторых сортов винограда в условиях Московской области. Бюллетень Главного ботанического сада АН СССР, вып. 24, lk. $51-58$.

Генкель П. А., Окн и на Е. 3., 1954. Диагностика морозоустойчивости растений по глубине покоя тканей и клеток. Москва.

Д а в и т а я Ф. Ф., 1948. Климатические зоны винограда в СССР. Москва.

До м бков ск а я Я. А., 1953. Значение фенологических наблюдений на виноградниках. Виноделие и виноградарство, № 5, 1k. 46-48.

К окин А. Я., В и лко в а А. Г., 1955. Некоторые данные к биохимической характеристике морозоустойчивости различных сортов яблонь. Биохимия плодов и овощей. М., lk. 79-90.

Л а з а р и с С. А., 1952. Виноградарство в средней полосе РСФСР. Москва.

Нег руль А. М., Ску инь К. П., 1955. Работа с культурой винограда в Московской ордена Ленина Сельскохозяйственной академии им. К. А. Тимирязева. Селекция винограда в СССР. Москва, lk. 98-109.

Н ег р уль А. М., 1956. Виноградарство. Москва.

Окнин а Е. 3., Куз ьмин А. Я., 1955. Изучение глубины покоя у винограда как фактор морозоустойчивости в условиях северного виноградарства. Труды Института физиологии растений им. К. А. Тимирязева, т. IX, 1k, 106-142.

По т а пе нко Я. И., З а х а ров а Е. И., 1937. Реакция винограда на световые и тепловые условия развития. В сб.: «Селекция плодово-ягодных растений». М.-Л.

С ерге ев Л. М., 1953. Выносливость растений. Москва.

С ерге е в Л. И., 1956. О роли крахмала при повреждении растений морозом. Бюллетень Главного ботанического сада АН СССР, вып. 25.

Р у б и н Б. А., 1949. О роли ферментативных процессов во взаимоотношениях растений с внешней средой. В сб.: «Проблемы биохимии и мичуринской биологии», № I. M.

Tartu Riiklik Olikool

Saabus toimetusse

27. V 1958 


\title{
О БИОЛОГИЧЕСКОЙ ХАРАКТЕРИСТИКЕ СОРТОВ ВИНОГРАДА, КУЛЬТИВИРУЕМЫХ В ЭСТОНСКОИ ССР
}

\author{
Х. И. Мийдла
}

Резюме

Выращивание винограда в Эстонии, несмотря на неблагоприятные климатические условия; стало возможным сравнительно с давних пор. Объясняется это легкой прнспособляемостью этой культуры к новым условиям произрастания. При разведении в более северных условиях, например в Эстонской ССР, внноград упорно сохраняет некоторые свои филогенетические особенности, вследствие чего процесс вызревания этого южного теплолюбивого растения короткого дня протекает в наших условиях длинного дня медленнее, чем на его родине.

При сравнении винограда, разводимого в условиях Эстонской ССР, с виноградом, растущим на юге, между ними не наблюдается существенных различий в прохождении фенофаз. Выясняется, что в наших условиях физиологическне процессы протекают v винограда с той же интенсивностью или даже интенсивнее, чем в южных условиях. Отклонения наблюдаются лишь при прохождении последней фенофазы, которая вследствие короткого вегетационного периода не успевает закончиться своевременно на материке Эстонской ССР. Однако на островах и западном побережье Эстонии прохождение последней фазы совершается нормально, что создает предпосылки для выращивания этой культуры в условиях этих районов.

В связи с отклонениями от нормального прохождения последней фазы цикла вегетации, процесс вызревания побегов у винограда в условиях материка Эстонской ССР происходит слабо, что в свою очередь оказывает влияние на его зимостойкость.

При подборе подходящих сортов, наличии подходящего микроклимата и применении соответствующих агротехнических приемов можно влиять на скорость созревания ягод и вызревания побегов у винограда.

Хорошее вызревание побегов, заключающееся в процессе одревесения и опробковения их, следует считать одной из важных предпосылок для успешной перезимовки кустов винограда.

Вызревание побегов зависит от интенсивности процесса отложения крахмала. При вызревании побегов процент крахмала повышается, процент же сахара понижается.

Динамика продуктивности фотосинтеза у различных видов винограда неодинакова, что является одним из показателей степени акклиматизации вида.

Глубина залегания корневой системы винограда, выращиваемого в Эстонской ССР, зависит от почвенных условий и видовых особенностей. При посадке винограда в неподготовленную почву основная масса корней располагается на глубине $20-40$ см. Во избежание повреждений от морозов посадку винограда следует производить на годготовленной почве и на глубину не менее $60 \mathrm{~cm}$. В бесснежные зимы почву следует покрывать органическим материалом, чтобы температура в зоне корневой массы не падала ниже $-5^{\circ} \mathrm{C}$.

Из разводимых в ЭССР видов винограда наиболее морозоустойчивыми оказались Parthenocissus quinquefolia var. murorum (Rehd.), Vitis amurensis (Rupr.) и copт Буйтур.

Сравнительно морозоустойчивыми являются гибриды с признаками $V$. riparia (Michx.) и V. amurensis (Rupr.), например сорта Альфа и Потапенко № 10. Виды $V$. vinifera (L.) являются сравнительно слабоустойчивыми к морозам и нуждаются до наступления зимы в пригибании кустов к земле и легком накрытии их.

Из разводимых в неотапливаемых оранжереях сортов лучшими следует считать Бродланд, Гамбург черный и Мускат александрийский; из пристенных культур - Мадлен роаяль и Маленгр ранний; из сортов, разводимых в открытом грунте, - Триумф и Мадлен Анжевин.

Тартуский

государственный университет
Поступила в редакцию 27 V 1958 


\section{DIE BIOLOGISCHE CHARAKTERISTIK DER IN DER ESTNISCHEN SSR ANGEBAUTEN WEINREBEN}

\section{H. Miidla}

\section{Zusammenfassung}

Die Weinrebe ist in der Estnischen SSR keine neue Kultur; dank ihrer Plastizität hat sie sich in unseren ungünstigen klimatischen Verhältnissen bis heute gehalten. Bei der vegetativen Vermehrung hat sie iedoch auch ihre phylogenetischen Eigenschaften bewahrt, weshalb die wärmeliebende Kurztagpilanze im Norden unter den Bedingungen des Langtages nur schlecht verholzt.

Ein Vergleich der in der Estnischen SSR gedeihenden Weinrebe mit ihren südlichen Arten lässt bei der ersteren während der Vegetationsperiode alle Phänophasen deutlich erkennen, wobei alle biologischen Prozesse ebenso intensiv wie im Süden, oder gar noch intensiver verlaufen. Eine Ausnahme ist bloss die letzte Phase, da ihr normaler Verlauf wegen der kurzen Vegetationsperiode auf dem estländischen Festland ausgeschlossen ist. Doch verläuft sie auf den Inseln und an den Meeresküsten normal, was Voraussetzungen für den Anbau dieser Kultur in den genannten Gebieten schafift.

$\mathrm{Da}$ die letzte Phänophase unvollständig ist, entwickelt sich der Reifungsprozess der einjährigen Triebe nur schwach, was sich wiederum auf der Winterfestigkeit auswirkt.

Durch die Wahl passender Sorten, durch günstige mikroklimatische Verhältnisse und geeignetes agrotechnisches Verfahren kann das Reifen der Traube wie auch der Rebe beschleunigt werden.

Stark ausgereifte Reben garantieren eine gute Oberwinterung, die sich in der Verholzung und Verkorkung äussert.

Die Stärkeablagerung steht im Zusammenhang mit der Ausreifung der Rebe.

Während der Ausreifung der Rebe steigt ihr Stärkeprozentsatz, ihr Zuckerprozentsatz aber sinkt.

Die Tiefe der Bewurzelung der Weinrebe hängt von der Beschaffenheit des Bodens und von der Art der Weinrebe ab.

In unbearbeiteten Boden verpflanzt, beiindet sich die Hauptmasse ihrer Wurzeln in den lokalen Verhältnissen in einer Tiefe von etwa $20-40 \mathrm{~cm}$. Um Frostschäden zu vermeiden. empfiehlt es sich, die jungen Weinpflanzen bis zu $60 \mathrm{~cm}$ tief in gut bearbeiteten Boden einzupflanzen. In schneearmen Wintern ist der Boden mit organischem Material zu bedecken, so-dass die Temperatur in der Zone, wo sich die Hauptmasse der Wurzeln befindet, nicht unter $-5^{\circ} \mathrm{C}$ sinkt.

Die Dynamik der Photosynthese ist bei der Weinrebe ein wesentliches Merkmal ihrer Artzugehörigkeit.

Als die frostbeständigsten Arten haben sich Parthenocissus quinquefolia var. murorum (Rehd.), V. amurensis (Rupr.) und 'Buitur' erwiesen.

Relativ frosthart sind einige Hybridsorten von V. riparia (Michx.) und $V$. amurensis (Rupr.), wie z. B. 'Alfa' und 'Potapenko Nr. 10'. Die Sorten der Art V. vinifera sind relativ frostempfindlich, sie müssen vor Winterbeginn zur Erde gebogen und leicht bedeckt werden.

Von den Kalthaussorten haben sich 'Broadland', 'Black Hamburgh' und 'Muskat Aleksander', von den Spaliersorten 'Madeleine Royal' und 'Früher Malingre', von den Freilandsorten 'Triumph' und 'Madeleine Angevine' bewährt. 